\title{
Motivations And Barriers In Undergraduate Students' Decisions To Enroll In Placement Courses In The UK
}

Maria Elisavet Balta, Ph.D., Brunel University, United Kingdom

Jane-Lisa Coughlan, Ph.D., Brunel University, United Kingdom

Peter Hobson, Ph.D., Brunel University, United Kingdom

\begin{abstract}
Due to recent changes in higher education and the increased demand for highly qualified candidates in the labor market, the employability of U.K. graduates has become a key performance indicator for universities. Institutions of higher education attempt to address employability by delivering a skilled workforce that will ensure the U.K.'s competitiveness in a global context. Placements are a proven mechanism for developing employability and, as such, this study aims to investigate the reasons behind students' decisions to take a placement or nonplacement course. Based on a self-administered, online questionnaire completed by 71 placement and 117 non-placement students from three schools, the study explores the reasons why students take or do not take a placement course. Finally, recommendations are made for ways to overcome potential work placement barriers and to promote placements to students, parents, and academic tutors as well as to advertise the benefits of work-based learning for employability.
\end{abstract}

Keywords: Work Placements; Motivations; Work-Based Learning; Student Employability

\section{INTRODUCTION}

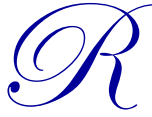

ecently, there has been an increased interest in work-based learning within higher education (Blackwell et al., 2001; Brennan and Little, 2006). Employers exert pressure on higher education institutes to produce knowledgeable, highly skilled, work-ready graduates due to the chasm between what the industry wants and what universities provide (Medhat, 2003).

The publication of two recent reports by Lambert (2003) and Leitch (2006) stressed the changes in the perspectives and understanding of business-university collaborations and of higher education and skills in the workforce. More recently, the Department for Business, Innovation and Skills (BIS, 2009, p. 40) identified the need to promote more work-based learning and "empower universities to be world leaders in the growing market in transnational education based on e-learning" as well as equip "Britain's workforce for a global economy."

Two governmental policy reviews in the U.K.'s higher education sector - the Dearing Review of Higher Education (1997) and the Skills' White Paper on Higher Education (2003) - highlight the importance of work-based learning in higher education. The Dearing Report (1997) recommends that universities should provide students with the opportunity to undertake work-based learning, while the White Paper stresses the contribution higher education makes to the economic and social well-being of the nation by producing future graduates with appropriate and relevant skills.

Previous studies have extensively discussed the benefits associated with work placement courses for students' future employability and academic achievements (e.g., Bowes and Harvey, 2000; Davies, 2003; Little and Harvey, 2006; Mandilaras, 2004). Placements are designed to help students gain confidence, learn new skills, and achieve a better working life (Page, 2004). Career exploration, training opportunities, and competitive advantage in 
both the graduate labor market and salary competition are key expectations students have regarding their work placement (Falconer and Pettigrew, 1993; Parilla and Hesser, 1998; Ryan et al., 1996). However, no previous study has explored the reasons that encourage or dissuade undergraduate students from enrolling in placement courses.

This study fills this gap in the existing literature by identifying the motivations and barriers for undergraduate students to take up placement courses. The paper proceeds as follows: The first section discusses the current transformation in the U.K. higher education and labor market. The second section highlights the motivations and the barriers faced by undergraduate students. Next, we describe the sample frame of the study and data collection approach. The section that follows reports the findings of the study and reveals the key reasons behind students' decisions to seek a placement. Finally, the paper suggests several ways that placements can be promoted to current and potential students, their parents, and educators.

\section{The Changing Context of Higher Education and the Labor Market}

The higher education system in the U.K. has undergone major changes. Specifically, the number of graduates has significantly increased by 6\% during the last 10 years (Brown, 2010; OECD, 2003).

Employers have expressed their concerns that undergraduate programs are failing to provide graduates with the necessary skills for their future employability (De la Harpe et al., 2000). Criticism has been leveled at business schools for being disconnected and incapable of preparing people to work in the real world (Clarke, 2008). The employability skills that employers currently seek can only be learned in "real-life" situations, even on a temporary basis such as work placements of two or three weeks. There is a limit to the extent that educational establishments can "teach" the necessary skills and attributes, even where extensive efforts are made to simulate the work environment (Johnson and Burden, 2003, p. 39). Employers in the retail and hospitality industries are looking for workers with industry engagement and pedagogical skills, and they stress the need for educators and trainees to emphasize "service ethics" to their students.

Due to the increased number of graduates, employers now target those with high "A" level points irrespective of degree attainment, as well as students from "elite" higher education institutions (HEFCE, 2002). They also look for flexible graduates who can add value and contribute with their personal and interpersonal skills to organizational transformation (Harvey et al., 2003).

The global financial crisis has either suspended or greatly reduced the graduate employment rate in many sectors. The economic downturn caused an increase in graduate unemployment from $11 \%$ at the end of 2008 to $14 \%$ by the end of 2011 (Higher Education Policy Institute, 2010). Graduates take jobs that do not require a degree and are often contract based (Davies, 2003). This leads to unprecedented levels of debt for students and fewer "good" jobs that successive governments have promised. The number of graduates is increasing on an annual basis, and the job market is becoming oversaturated. This has led to strong competition among graduates without obvious "returns" for higher education.

In addition, the highly publicized Browne report suggested restructuring in the current U.K. higher education tuition fee, loan, and funding process by lifting the cap on tuition fees and allowing tuition fee chargers to increase from $£ 3290$ to a maximum of $£ 9,000$ a year. According to the "Student Finance Plan," graduates who earn over $£ 21,000$ annually will pay their tuition fees back to the government, a rise from the current minimum income of $£ 15,000$. These policy changes highlight the government's recognition of the importance of producing qualified graduates.

The National Committee of Inquiry into Higher Education (Dearing, 1997) responded to the current demands by encouraging universities to incorporate courses with work-based learning into their curriculum, as work-based learning enhances students' employability and increases placement opportunities (e.g., Barthorpe and Hall, 2000; Wilson et al., 2000). Since 1980, the curriculum focus has transformed from liberalism to vocationalism, and now universities have incorporated vocational elements that emphasize the application and utilization of knowledge. Therefore, students can apply their academic theoretical knowledge in practice (Auburn and Ley, 2003; Deissinger, 2000). Universities must engage with the employability agenda and equip students with career building 
and self-management skills in order to remain competitive in a diverse training market (Bridgestock, 2009). In the current context, universities are expected to play a key role in producing graduates ready for the workforce (Gomez, Lush, and Clements, 2004).

Higher education institutions contribute to the industry through work placements. Personal development programs that teach transferable skills and enhance employability are now a feature of most degrees in the U.K. (Connor and Shaw, 2008). In the academic year 2009-10, 117,685 students were enrolled in placement courses in U.K. (HESA, 2011). This high number is due to the increased pressure placed on the system of higher education to produce more employable graduates and to meet employers' expectations. Employers tend to appreciate university graduates who had undertaken periods of work experience during their studies (Bowes and Harvey, 2000; Harvey et al., 1997). They expect graduates to have core competencies needed in the workplace (Birks, 1996; Johnson, 2000). The challenge now will be for universities to provide work placement that will help students to develop transferable skills and, at the same time, provide a learning environment at a suitable academic level (Jackson, 1995; Wrennall and Forbes, 2002; Young, 1995). Next, we discuss the motivations and barriers for students to seek placement.

\section{Motivations for Students to Enroll in Placement Courses}

Placement courses aim to provide students with practical experience in the application of theoretical concepts, to further their understanding of the purpose and meaning of an organization, to promote their personal development, to learn additional practical skills, and to enhance their career prospects (Freudenberg et al., 2011). Many students these days work not just to meet their living expenses, but also to gain work experience (Broadbridge and Swanson 2005; Hall, 2010). Motivation toward placement derives from the benefits associated with placement, including employability enhancement, skills, possibility of improving academic grades, experiences that students feel are missing from their course, the opportunity to extend their learning into a different area (i.e., a chance to test whether they would like to work in a particular position or industry), or even a break from an academic career (Little and Harvey, 2006).

It has been widely accepted that work placement provides students with the opportunity to apply the theoretical knowledge gained through their undergraduate programs into business practice (Hughes, 1998). The placement experience enriches students' existing theoretical knowledge and contributes to their academic understanding. Work placement places the learner "at an interface of different cultures, exploring work-focused and work-related issues in the context of university knowledge, scholarship, and values" (University of Leeds, 1996, cited in Brennan and Little, 1996). It allows students to experience the application of theory and practice, using examples from the industry field (Alderman and Milne, 1998). Clearly, work placement provides a different learning environment from the university. Learning at a university is typically formal and guided, whereas work placement experiences tend to encourage informal and incidental learning (Hughes, 1998; Jackson, 1995). The learning process in work placement usually involves reflection on experience, self-management, and individual responsibility for personal and professional development. Students in placement courses are able to integrate both theory and practice; in contrast, students who choose not to participate in placement do not achieve such integration (Foster, 1998).

Wilton (2008) reported that work placement graduates show a greater development of organizational, leadership, management, entrepreneurship skills, and the ability to work in teams. Falconer and Pettigrew (1993) have identified a number of skills that are developed through work placement learning, such as communication, problem solving, and organization and interpersonal skills. These skills might not be directly related to academic performance, but they improve academic achievement. Mandilaras $(2004$, p. 39) stated that "the statistical analysis offers evidence that participation in the placement scheme significantly increases the chances of obtaining an upper second or higher degree class." Gomez et al. (2004, p. 373) further commented that "on average, placement students gain an advantage of nearly $4 \%$ in their final year performance." Other scholars (e.g., Barthorpe and Hall, 2000; Marshall and Cooper, 2001) as well as the Council for National Academic Awards (Davies, 2003) and the Confederation of British Industry's Higher Education Task Force (2009) have supported these arguments.

Career enhancement, career switching, and personal development are regarded as the key motivations for students to enroll in placement courses (Schonfield, 2005). Through placement, students gain confidence, learn new skills, and achieve a better working life (Page, 2004). Gault et al. (2010) and Mortimer and Wilkinson (2003) found 
that two or three years after graduation, graduates receive high-quality job offers. Placement course graduates are more qualified and perform better in the work place compared to their counterparts who have undertaken nonplacement courses (Blackwell and Harvey, 1999; Bowes and Harvey, 2000; Harvey et al., 2003). Moreover, graduates who have been on an industrial placement are more committed and more adaptable (Leslie and Richardson, 2000), and they have acquired superior transferable skills (Davison et al., 1993; Ellis, 2000). Thus, placements prepare graduates for entry into the labor market in terms of not only skill development but also, mainly, dealing with responsibility in shaping their work and developing self-confidence (Wilton, 2008).

\section{Barriers to Enrollment in Placement Courses}

In the U.K., higher education institutions have experienced a decline in the number of students who participate in placement, from almost 29,000 to 20,400 (Little and Harvey, 2006). In the period from 1999 to 2003, the number of students increased by $9.1 \%$, while the number of graduates fell $7.1 \%$ (Higher Education Funding Council for England [HEFCE], 2009).

A number of barriers to the provision of placement experience have emerged. Higher education and the labor market have changed dramatically in recent years, with higher education moving from an elite to a mass system, through middle-class students becoming widely represented in higher education (Archer et al., 2000; Moreau and Leathwood, 2006). Applications to study at universities in the U.K. are at an all-time high, with $45 \%$ of people aged 18 to 30 entering higher education, a 6\% increase from 10 years ago (Brown, 2010). These changes have increased the demand for student placements, particularly in the business and management fields. On the other hand, there are not enough work placements available to meet the demand from schools, colleges, and universities. For employers, this means an increased resource cost to respond to the large number of requests received. For institutions, it means that finding work experience for students can often be time consuming and difficult and is not always successful. Another interesting feature that has emerged is the reduced demand for placements from students (HEFCU, 2010). This concurs with a recent study by Walker and Ferguson (2009) looking at the downward trend in students who choose placements.

The location of the employer appears to be a barrier for students to undertake a placement course for three reasons. First, institutions in less populated or rural areas have fewer local employers willing or able to offer placements. Second, it is harder for students to obtain a placement if their institution is located in a highly competitive area. Finally, placements that are geographically dispersed might cause travel inconveniences (i.e., commuting time, transportation cost). Additionally, students are reluctant to move away from their homes (NCWE, 2006).

Further, unrealistic expectations or inadequate knowledge of the nature of the industry are additional barriers. There is a "disconnect" between what employers offer and what students can deliver (Page, 2004). For example, students often expect to be placed in big multinational firms, where there is high competition and limited opportunities. However, recently, small and medium sized enterprises have had an increased demand for graduates (Dale and Kerr, 1995; DTI, 2000).

In addition, students might face difficulties securing a placement due to poor academic performance or lack of previous experience or core competencies that employers require. Poor academic performance sometimes causes the employer to doubt the student's ability to be an effective and productive employee. It may also mean that the student requires additional training and time from the employer in order to adjust to the work environment. Finally, students may be reluctant to enroll in a placement course that is not related to their studies, especially mature students who are interested in completing their degree quickly (NCWE, 2006).

Schonfield (2005) found three primary barriers that individuals face in pursuing the graduate management degree - the application process, financing their education, and the program's time commitment. Financial restriction is another barrier in their decision to seek a placement degree. Page (2004) stated that "students are worried about debt and want to start work sooner. Lots of them think that a degree is enough, but it is not anymore. They need practical experience but they also wish to finish their schooling as quickly as possible to start earning a salary." Similarly, McMahon and Quinn (1995) pointed out that placement students face poor employment 
conditions and low salaries. Finally, commitment barriers refer to the time and energy that the respondents have to spend on pursuit of a placement course that will require them to postpone personal plans and to limit the time they spend with friends and family, including their children. This section has highlighted the difficulties that students come across taking up a placement.

The undertaking study aims to examine the reasons behind students' decision to apply for a placement or non-placement course across three schools within the same university - Business, Engineering and Design, and Information Systems, Computing, and Mathematics.

\section{METHODOLOGY}

The study was carried out at Brunel University, which was founded in the 1960s in West London, Uxbridge, and is well known and respected in engineering circles. Brunel University started as a technological college and offered courses with a work placement component, a new concept at the time. Today, it has extended far beyond the fields of engineering, science, and technology, having established a strong name in other schools such as Business, Information Systems, Social Sciences, Health Care, and Education. Brunel University consists of 16,000 people, including both staff and students.

Brunel University is currently regarded as the U.K. leader in placement courses, as its staff members believe that the addition of work experience to a traditional degree creates graduates who are more confident, experienced, and appealing to employers. Brunel University is a truly diverse and multi-cultural community. Its students represent more than 150 nationalities from around the world. The university remains committed to its traditional roots in academic rigor and quality while maintaining a flexible and responsive approach to an evolving market.

The Placement and Careers Centre (PCC) works with students on placement courses, which can be either two six-month placements (one in Year 2 and one in Year 3) or a yearlong placement in Year 3. Placement courses last four years so there is no reduction in the teaching element. The PCC facilitates student placement searches in a variety of ways through well-established links with public and private sector employers. They not only provide help with applications and curricula vitae (CVs) but also offer advice and guidance for students and graduates on a range of topics from career options and planning to succeed in the recruitment process.

Data were drawn from Brunel undergraduate students: 71 students on a placement and 117 on a nonplacement course. The sample of placement students consisted of 42 Business, 13 Engineering, and 16 Information Systems students, whereas the non-placement student sample consists of 6 Business, 36 Engineering and 17 Information Systems students. The data were collected through questionnaires completed by students come from three schools - Business, Engineering and Design, and Information Systems, Computing, and Mathematics. The questionnaire was pilot tested through two focus groups: one with non-placement students and the other with placement students. The pilot survey helped us to ensure question completeness, efficiency, and format completeness before the launch of the survey.

Focus groups cultivate the expression of ideas and encourage the group members to participate and speak (Denzin, 1989; Frey and Fontana, 1993). The findings that emerged from the focus groups gave us insightful information on the factors that influenced students to switch to a non-placement degree. Some students disclosed that they had to change to a full time course because they were struggling to finish their studies and had a heavy load of assignment deadlines. Others cited their lack of previous work-related experience, which would have made the job application process more complex and may have increased their rejection rate. In addition, some students who had been on a placement claimed that students who have attended several training preparatory activities have a higher chance of obtaining a placement.

Quantitative data on the students' perceptions about the motivations and barriers to enrolling in placement courses were collected using a questionnaire-based survey method. The different questionnaires were designed for full time and placed students in accordance with Dillman's (2000) Total Design Method. Questionnaires were distributed in an electronic and hard copy format to full-time and placed undergraduate students of Business, 
Engineering and Design, and Information Systems, Computing, and Mathematics over the period of September 2009 to August 2010.

The survey for non-placement students included information on their demographics, previous and type of work experience, confidence level, and reasons for choosing a non-placement course. A separate survey was sent to students who had been on a placement; this survey asked about their demographic characteristics, the location of their placement employer, payment rate, motivations for choosing a placement course, and its value.

\section{RESULTS AND DISCUSSION}

The section below provides an overview of the reasons and factors that influence undergraduate students to pursue a non-placement or placement course. It presents the findings from (1) students on a non-placement course and (2) students on a placement course.

\section{Non-Placement Course Students}

The sample of non-placement students consisted of 64 Business, 36 Engineering and Design, and 17 Information Systems, Computing, and Mathematics students.

\section{Previous work experience}

The majority of non-placement students (i.e., 69\% of Business, 52\% of Engineering and Design, and almost $80 \%$ of Information Systems students) reported having work experience of up to one month (Table 1). Their work experience had typically been at either the school or college they attended. The lack of enough previous work experience shows lack of dedication and commitment by the student or poor or lack of teamwork, communication, and interview skills. Prior work experience helps the supply of highly educated people with certain employability skills that are widely recognized by employers (Archer and Davidson, 2008; Universities UK/CBI, 2009; Mason et al., 2009). Through work experience, students acquire transferable skills such as teamwork, self-management, and communication skills (Curtis and Shani, 2002). These skills enable them to develop awareness about themselves, their relationships with others and the organization that they work for (Brennan and Little, 2006). Students who have undertaken previous jobs are more likely to be employed after their graduation. However, a lack of previous related or even unrelated work experience is regarded as a barrier to enrolling in a placement course.

Table 1

Previous and Type of Work Experience: Non-placement Students

\begin{tabular}{|c|c|c|c|c|}
\hline $\begin{array}{l}\text { Amount of previous work } \\
\text { experience }\end{array}$ & Business School & $\begin{array}{l}\text { School of Engineering } \\
\text { and Design }\end{array}$ & $\begin{array}{l}\text { School of Information } \\
\text { Systems, Computing, } \\
\text { and Mathematics }\end{array}$ & Total \\
\hline None & $\begin{array}{c}9 \\
(31 \%)\end{array}$ & $\begin{array}{c}14 \\
(48 \%)\end{array}$ & $\begin{array}{c}3 \\
(23 \%)\end{array}$ & $\begin{array}{c}26 \\
(36 \%)\end{array}$ \\
\hline Up to 1 month & $\begin{array}{c}20 \\
(69 \%)\end{array}$ & $\begin{array}{c}15 \\
(52 \%)\end{array}$ & $\begin{array}{c}10 \\
(80 \%)\end{array}$ & $\begin{array}{c}45 \\
(63 \%)\end{array}$ \\
\hline \multicolumn{5}{|l|}{ Type of work experience } \\
\hline $\begin{array}{l}\text { Work experience organized } \\
\text { by my school or college }\end{array}$ & $\begin{array}{c}34 \\
(53 \%)\end{array}$ & $\begin{array}{c}12 \\
(33 \%)\end{array}$ & $\begin{array}{c}11 \\
(65 \%)\end{array}$ & $\begin{array}{c}57 \\
(49 \%)\end{array}$ \\
\hline Work shadowing & $\begin{array}{c}1 \\
(2 \%)\end{array}$ & $\begin{array}{c}4 \\
(11 \%)\end{array}$ & $\begin{array}{c}1 \\
(6 \%)\end{array}$ & $\begin{array}{c}6 \\
(5 \%)\end{array}$ \\
\hline Volunteer work & $\begin{array}{c}9 \\
(14 \%)\end{array}$ & $\begin{array}{c}4 \\
(11 \%)\end{array}$ & $\begin{array}{c}0 \\
(0 \%)\end{array}$ & $\begin{array}{c}13 \\
(11 \%)\end{array}$ \\
\hline Internship & $\begin{array}{c}9 \\
(14 \%)\end{array}$ & $\begin{array}{c}5 \\
(14 \%)\end{array}$ & $\begin{array}{c}1 \\
(6 \%)\end{array}$ & $\begin{array}{c}15 \\
(13 \%)\end{array}$ \\
\hline Summer job & $\begin{array}{c}11 \\
(17 \%)\end{array}$ & $\begin{array}{c}11 \\
(31 \%)\end{array}$ & $\begin{array}{c}4 \\
(24 \%)\end{array}$ & $\begin{array}{c}26 \\
(22 \%)\end{array}$ \\
\hline
\end{tabular}


Level of confidence

Students were asked to tell us how confident they felt about securing a graduate job after their graduation. Non-placement students' level of confidence was not high (Table 2). They either feared application rejections or did not consider themselves as well qualified to apply. This low level of confidence is associated with lack of social skills and inability to take up responsibilities (Stoner and Milner, 2008). The survey results showed that students with low levels of confidence choose to take non-placement courses. These students have low self-confidence because they have not been on a placement to achieve a greater degree of personal independence, responsibility, and maturity (Breathnach, 1983). Students can lack the self-confidence to tackle some aspects of writing applications, to call to enquire about placement opportunities, and to negotiate a work placement framework (Page, 2004). The importance of "the level of confidence has been widely mentioned by universities, employers and students as a beneficial outcome of work-related learning and formal work placements" (Confederation of British Industry, 2009, p. 17).

Table 2

Level of Confidence: Non-placement students

\begin{tabular}{|l|c|c|c|c|}
\hline & Business School & $\begin{array}{c}\text { School of Engineering } \\
\text { and Design }\end{array}$ & $\begin{array}{c}\text { School of Information } \\
\text { Systems, Computing, } \\
\text { and Mathematics }\end{array}$ & $\begin{array}{c}\text { Total } \\
3\end{array}$ \\
\hline Very confident & 3 & 6 & $(18 \%)$ & 12 \\
$(10 \%)$ & $(17 \%)$ & $(6 \%)$ & 20 \\
\hline Confident & $(5 \%)$ & 6 & 2 & $(17 \%)$ \\
\hline Quite confident & $(20 \%)$ & $(17 \%)$ & 9 & $(21 \%)$ \\
\hline Not confident & 15 & $(22 \%)$ & $(53 \%)$ & 42 \\
& $(23 \%)$ & 10 & 1 & $(36 \%)$ \\
\hline $\begin{array}{l}\text { I do not know what graduate } \\
\text { career I want. }\end{array}$ & 23 & $(28 \%)$ & $(6 \%)$ & 13 \\
\hline $\begin{array}{l}\text { I do not intend to go straight } \\
\text { into a graduate job. }\end{array}$ & $(36 \%)$ & 4 & 1 & $(11 \%)$ \\
\hline
\end{tabular}

Reasons for choosing a non-placement course

Non-placement students from the three schools were asked to reveal the factors that influenced their choice to enroll in a non-placement course. Students from Business (30\%), Engineering (11\%), and Information Systems (24\%) wanted to focus on achieving a 2.1 or $1^{\text {st }}$ degree classification (Table 3 ). They were concerned that if they applied for a placement course, they would have to spend time preparing their CVs, applying for placements, and attending interviews, whereas in a non-placement course, they could focus on their studies. A majority of students receive a placement position after applying for more than 10 positions. As Page (2004) has explained, some students choose not to take a placement because they want to finish their studies as quickly as possible, in order to enter the labor market and start earning a salary. They may be influenced to do so by financial debts or the responsibility of having dependents. Although, work experience is gaining importance in the increasingly competitive graduate market, unfortunately, placement might not be an option for all students, due to financial debts that can force some to rely on part-time work to support their studies. Finally, a key factor that inhibits students from applying for placements is the fear of application rejection. Students might feel disheartened after their first rejection and quit the process as a result. Their choice can be attributed to a lack of persistence. To solve the issue, they should be encouraged not only to keep trying but also to find alternative placement options such as within small and medium enterprises (SMEs). 
Table 3

Key Reasons for Choosing a Non-Placement Course

\begin{tabular}{|c|c|c|c|c|}
\hline & Business School & $\begin{array}{c}\text { School of } \\
\text { Engineering and } \\
\text { Design }\end{array}$ & $\begin{array}{c}\text { School of } \\
\text { Information } \\
\text { Systems, } \\
\text { Computing, and } \\
\text { Mathematics }\end{array}$ & Total \\
\hline $\begin{array}{l}\text { I wanted to finish my degree as quickly } \\
\text { as possible. }\end{array}$ & $\begin{array}{c}12 \\
(19 \%)\end{array}$ & $\begin{array}{c}9 \\
(25 \%) \\
\end{array}$ & $\begin{array}{c}2 \\
(12 \%) \\
\end{array}$ & $\begin{array}{c}23 \\
(20 \%) \\
\end{array}$ \\
\hline $\begin{array}{l}\text { I thought I would be worse off } \\
\text { financially if I did a placement. }\end{array}$ & $\begin{array}{c}0 \\
(0 \%) \\
\end{array}$ & $\begin{array}{c}1 \\
(3 \%)\end{array}$ & $\begin{array}{c}0 \\
(0 \%)\end{array}$ & $\begin{array}{c}1 \\
(1 \%)\end{array}$ \\
\hline My friends were not doing a placement. & $\begin{array}{c}2 \\
(3 \%)\end{array}$ & $\begin{array}{c}2 \\
(6 \%)\end{array}$ & $\begin{array}{c}1 \\
(6 \%)\end{array}$ & $\begin{array}{c}5 \\
(4 \%) \\
\end{array}$ \\
\hline $\begin{array}{l}\text { I did not think it would affect my } \\
\text { employability. }\end{array}$ & $\begin{array}{c}4 \\
(6 \%) \\
\end{array}$ & $\begin{array}{c}4 \\
(11 \%) \\
\end{array}$ & $\begin{array}{c}0 \\
(0 \%)\end{array}$ & $\begin{array}{c}8 \\
(7 \%)\end{array}$ \\
\hline $\begin{array}{l}\text { I have not started thinking about my } \\
\text { future career. }\end{array}$ & $\begin{array}{c}7 \\
(11 \%) \\
\end{array}$ & $\begin{array}{c}3 \\
(8 \%) \\
\end{array}$ & $\begin{array}{c}1 \\
(6 \%) \\
\end{array}$ & $\begin{array}{c}11 \\
(9 \%)\end{array}$ \\
\hline I was not prepared to relocate. & $\begin{array}{c}2 \\
(3 \%)\end{array}$ & $\begin{array}{c}1 \\
(3 \%)\end{array}$ & $\begin{array}{c}0 \\
(0 \%)\end{array}$ & $\begin{array}{c}3 \\
(3 \%)\end{array}$ \\
\hline $\begin{array}{l}\text { My friends or family did not encourage } \\
\text { me to do a placement. }\end{array}$ & $\begin{array}{c}0 \\
(0 \%)\end{array}$ & $\begin{array}{c}1 \\
(3 \%)\end{array}$ & $\begin{array}{c}0 \\
(0 \%)\end{array}$ & $\begin{array}{c}1 \\
(1 \%)\end{array}$ \\
\hline $\begin{array}{l}\text { I was put off by the time/effort needed } \\
\text { for applications. }\end{array}$ & $\begin{array}{c}10 \\
(16 \%) \\
\end{array}$ & $\begin{array}{c}2 \\
(6 \%) \\
\end{array}$ & $\begin{array}{c}0 \\
(0 \%) \\
\end{array}$ & $\begin{array}{c}12 \\
(10 \%) \\
\end{array}$ \\
\hline $\begin{array}{l}\text { I did not want to risk application } \\
\text { rejections. }\end{array}$ & $\begin{array}{c}1 \\
(2 \%) \\
\end{array}$ & $\begin{array}{c}1 \\
(3 \%) \\
\end{array}$ & $\begin{array}{c}0 \\
(0 \%) \\
\end{array}$ & $\begin{array}{c}2 \\
(2 \%) \\
\end{array}$ \\
\hline $\begin{array}{l}\text { I wanted to concentrate on getting a } 2.1 \\
\text { or } 1^{\text {st }} \text { degree classification }\end{array}$ & $\begin{array}{c}19 \\
(30 \%)\end{array}$ & $\begin{array}{c}4 \\
(11 \%) \\
\end{array}$ & $\begin{array}{c}4 \\
(24 \%) \\
\end{array}$ & $\begin{array}{c}27 \\
(23 \%) \\
\end{array}$ \\
\hline None of the above & $\begin{array}{c}7 \\
(11 \%)\end{array}$ & $\begin{array}{c}8 \\
(22 \%)\end{array}$ & $\begin{array}{c}9 \\
(53 \%)\end{array}$ & $\begin{array}{c}24 \\
(21 \%)\end{array}$ \\
\hline Total & $\begin{array}{c}64 \\
(100 \%)\end{array}$ & $\begin{array}{c}36 \\
(100 \%)\end{array}$ & $\begin{array}{c}17 \\
(100 \%)\end{array}$ & $\begin{array}{c}117 \\
(100 \%)\end{array}$ \\
\hline
\end{tabular}

\section{Placement Course Students}

The placement course group consisted of 42 Business, 13 Engineering and Design, and 16 Information Systems, Computing, and Mathematics students.

\section{Previous work experience}

The results of a cross tabulation analysis showed $63 \%$ of students who obtained a placement did not have any previous career-related experience (Table 4). However, those who did (42\%) had more than a year of coursework related work experience, which had been arranged mainly through networking ties with friends of family members. The results show that students who have gained significant work experience, whether it is related to their degrees or not, are more likely to be employed. High levels of work employment are positively associated with some general aspects of employment such work preparation and finding a satisfying job (NCWE, 2006). Scholars (e.g., Harvey and Contributors, 2003; Harvey et al., 1997; Lambert et al., 2001; Purcell et al., 1999; Sewell, 2001) have mentioned that both large firms and SMEs believe work experience helps students to develop desirable attributes; therefore, they recommend that all courses include a form of work experience. Students with previous work experience have higher chances of obtaining full-time permanent employment after graduation and higher income (Blackwell and Harvey, 1999; Bowes and Harvey, 2000). 
Table 4

Previous Course or Career-Related Work Experience: Placement course students

\begin{tabular}{|c|c|c|c|c|}
\hline & Business School & $\begin{array}{l}\text { School of Engineering } \\
\text { and Design }\end{array}$ & $\begin{array}{l}\text { School of Information } \\
\text { Systems, Computing, } \\
\text { and Mathematics }\end{array}$ & Total \\
\hline Yes & $\begin{array}{c}17 \\
(41 \%) \\
\end{array}$ & $\begin{array}{c}6 \\
(46 \%) \\
\end{array}$ & $\begin{array}{c}3 \\
(19 \%) \\
\end{array}$ & $\begin{array}{c}26 \\
(37 \%) \\
\end{array}$ \\
\hline No & $\begin{array}{c}25 \\
(60 \%)\end{array}$ & $\begin{array}{c}7 \\
(54 \%)\end{array}$ & $\begin{array}{c}13 \\
(81 \%)\end{array}$ & $\begin{array}{c}45 \\
(63 \%) \\
\end{array}$ \\
\hline \multicolumn{5}{|l|}{ Amount of previous work experience } \\
\hline$<1$ month & $\begin{array}{c}3 \\
(18 \%)\end{array}$ & $\begin{array}{c}3 \\
(50 \%)\end{array}$ & $\begin{array}{c}1 \\
(33 \%)\end{array}$ & $\begin{array}{c}7 \\
(27 \%)\end{array}$ \\
\hline$>5$ months & $\begin{array}{c}14 \\
(82 \%) \\
\end{array}$ & $\begin{array}{c}3 \\
(51 \%) \\
\end{array}$ & $\begin{array}{c}2 \\
(66 \%) \\
\end{array}$ & $\begin{array}{c}19 \\
(73 \%) \\
\end{array}$ \\
\hline \multicolumn{5}{|l|}{ Type of work experience } \\
\hline $\begin{array}{l}\text { Work experience organized by my } \\
\text { school or college }\end{array}$ & $\begin{array}{c}0 \\
(0 \%)\end{array}$ & $\begin{array}{c}1 \\
(17 \%)\end{array}$ & $\begin{array}{c}0 \\
(0 \%)\end{array}$ & $\begin{array}{c}1 \\
(4 \%)\end{array}$ \\
\hline Volunteer work & $\begin{array}{c}4 \\
(24 \%)\end{array}$ & $\begin{array}{c}1 \\
(17 \%)\end{array}$ & $\begin{array}{c}0 \\
(0 \%)\end{array}$ & $\begin{array}{c}5 \\
(19 \%)\end{array}$ \\
\hline Internship & $\begin{array}{c}2 \\
(12 \%)\end{array}$ & $\begin{array}{c}0 \\
(0 \%)\end{array}$ & $\begin{array}{c}0 \\
(0 \%)\end{array}$ & $\begin{array}{c}2 \\
(8 \%)\end{array}$ \\
\hline Summer job & $\begin{array}{c}1 \\
(6 \%)\end{array}$ & $\begin{array}{c}1 \\
(17 \%)\end{array}$ & $\begin{array}{c}0 \\
(0 \%)\end{array}$ & $\begin{array}{c}2 \\
(8 \%)\end{array}$ \\
\hline Other advertised work experience & $\begin{array}{c}2 \\
(19 \%) \\
\end{array}$ & $\begin{array}{c}0 \\
(0 \%) \\
\end{array}$ & $\begin{array}{c}0 \\
(0 \%) \\
\end{array}$ & $\begin{array}{c}2 \\
(8 \%)\end{array}$ \\
\hline My own business/consultancy & $\begin{array}{c}1 \\
(6 \%)\end{array}$ & $\begin{array}{c}0 \\
(0 \%)\end{array}$ & $\begin{array}{c}0 \\
(0 \%)\end{array}$ & $\begin{array}{c}1 \\
(4 \%)\end{array}$ \\
\hline $\begin{array}{l}\text { Experience arranged through friends or } \\
\text { family }\end{array}$ & $\begin{array}{c}4 \\
(24 \%)\end{array}$ & $\begin{array}{c}2 \\
(33 \%)\end{array}$ & $\begin{array}{c}3 \\
(100 \%)\end{array}$ & $\begin{array}{c}9 \\
(35 \%)\end{array}$ \\
\hline $\begin{array}{l}\text { Experience gained through speculative } \\
\text { application }\end{array}$ & $\begin{array}{c}2 \\
(12 \%)\end{array}$ & $\begin{array}{c}0 \\
(0 \%)\end{array}$ & $\begin{array}{c}0 \\
(0 \%) \\
\end{array}$ & $\begin{array}{c}2 \\
(8 \%) \\
\end{array}$ \\
\hline Other & $\begin{array}{c}1 \\
(6 \%)\end{array}$ & $\begin{array}{c}1 \\
(17 \%)\end{array}$ & $\begin{array}{c}0 \\
(0 \%)\end{array}$ & $\begin{array}{c}2 \\
(8 \%)\end{array}$ \\
\hline
\end{tabular}

Location and remuneration of the placement

The findings reveal that that the majority of students across the three schools made the decision to seek a placement taking into account that they did not have to move out of their homes $(73 \%)$ and that placements offered them more than 100 pounds per week (87\%) (Table 5). These findings are in line with previous studies claiming that the location of the employer is a crucial matter in students' decisions (Ball et al., 2006). Students choose placements close to their homes in order to avoid long commutes and transport costs (Heaton et al., 2008; NCWE, 2006).

\section{Reasons for choosing a placement course}

The students were asked to identify the reasons they decided to enroll in a placement course. The findings indicate that $70 \%$ of Business, $62 \%$ of Engineering, and $56 \%$ of Information Systems students chose a placement course because they want to gain industry experience (Table 6). These students were motivated to seek a placement because they wanted to apply their theoretical knowledge in a commercial environment while developing core competencies such as teamwork, communication, negotiation, and problem solving skills. Moreover, they wanted to become familiar with professional practices, to raise their labor-market value, and enhance their employability opportunities (Dearing, 1997; Harvey et al., 1998; National Council for Work Experience [NCWE], 2002). Smith et al. (2002, p. 287) reported that placements contribute to the development of "dispositional workplace knowledge that increases employability [and] development of informed choice about career pathways transition into apprenticeships and further study." During their work placements, students develop personal skills and attributes (e.g., time management, self-confidence, and adaptability) and key interactive attributes (e.g., team work, interpersonal, and communication skills) (Harvey et al., 1998). 
Table 5

Placement Location and Salary

\begin{tabular}{|c|c|c|c|c|}
\hline & Business School & $\begin{array}{c}\text { School of Engineering } \\
\text { and Design }\end{array}$ & $\begin{array}{l}\text { School of Information } \\
\text { Systems, Computing, } \\
\text { and Mathematics }\end{array}$ & Total \\
\hline \multicolumn{5}{|l|}{ Location } \\
\hline I did not have to move. & $\begin{array}{c}34 \\
(81 \%)\end{array}$ & $\begin{array}{c}5 \\
(39 \%) \\
\end{array}$ & $\begin{array}{c}13 \\
(81 \%)\end{array}$ & $\begin{array}{c}52 \\
(73 \%)\end{array}$ \\
\hline$<50$ miles & $\begin{array}{c}0 \\
(0 \%)\end{array}$ & $\begin{array}{c}0 \\
(0 \%)\end{array}$ & $\begin{array}{c}2 \\
(13 \%) \\
\end{array}$ & $\begin{array}{c}2 \\
(3 \%) \\
\end{array}$ \\
\hline $50<100$ miles & $\begin{array}{c}3 \\
(7 \%)\end{array}$ & $\begin{array}{c}5 \\
(39 \%)\end{array}$ & $\begin{array}{c}1 \\
(6 \%)\end{array}$ & $\begin{array}{c}9 \\
(13 \%)\end{array}$ \\
\hline$>100$ miles & $\begin{array}{c}2 \\
(5 \%) \\
\end{array}$ & $\begin{array}{c}1 \\
(8 \%) \\
\end{array}$ & $\begin{array}{c}0 \\
(0 \%) \\
\end{array}$ & $\begin{array}{c}3 \\
(4 \%) \\
\end{array}$ \\
\hline$>200$ miles & $\begin{array}{c}2 \\
(5 \%) \\
\end{array}$ & $\begin{array}{c}1 \\
(8 \%) \\
\end{array}$ & $\begin{array}{c}0 \\
(0 \%) \\
\end{array}$ & $\begin{array}{c}3 \\
(4 \%) \\
\end{array}$ \\
\hline I moved overseas. & $\begin{array}{c}1 \\
(2 \%) \\
\end{array}$ & $\begin{array}{c}1 \\
(8 \%) \\
\end{array}$ & $\begin{array}{c}0 \\
(0 \%) \\
\end{array}$ & $\begin{array}{c}2 \\
(3 \%) \\
\end{array}$ \\
\hline \multicolumn{5}{|l|}{ Salary } \\
\hline It paid more than $£ 100$ a week. & $\begin{array}{c}36 \\
(86 \%) \\
\end{array}$ & $\begin{array}{c}10 \\
(80 \%) \\
\end{array}$ & $\begin{array}{c}16 \\
(100 \%) \\
\end{array}$ & $\begin{array}{c}62 \\
(87 \%) \\
\end{array}$ \\
\hline It paid less than $£ 100$ a week. & $\begin{array}{c}1 \\
(2 \%)\end{array}$ & $\begin{array}{c}1 \\
(8 \%)\end{array}$ & $\begin{array}{c}0 \\
(0 \%)\end{array}$ & $\begin{array}{c}2 \\
(3 \%)\end{array}$ \\
\hline It was completely unpaid. & $\begin{array}{c}1 \\
(2 \%) \\
\end{array}$ & $\begin{array}{c}0 \\
(0 \%) \\
\end{array}$ & $\begin{array}{c}0 \\
(0 \%) \\
\end{array}$ & $\begin{array}{c}1 \\
(1 \%)\end{array}$ \\
\hline Other & $\begin{array}{c}4 \\
(10 \%)\end{array}$ & $\begin{array}{c}2 \\
(15 \%)\end{array}$ & $\begin{array}{c}0 \\
(0 \%)\end{array}$ & $\begin{array}{c}6 \\
(9 \%)\end{array}$ \\
\hline
\end{tabular}

Table 6

Key Reasons for Choosing a Placement Course and Its Value

\begin{tabular}{|c|c|c|c|c|}
\hline & Business School & $\begin{array}{c}\text { School of Engineering } \\
\text { and Design }\end{array}$ & $\begin{array}{l}\text { School of Information } \\
\text { Systems, Computing, } \\
\text { and Mathematics }\end{array}$ & Total \\
\hline \multicolumn{5}{|l|}{ Reasons } \\
\hline $\begin{array}{l}\text { I hoped to get a graduate job with } \\
\text { my placement employer. }\end{array}$ & $\begin{array}{c}0 \\
(0 \%) \\
\end{array}$ & $\begin{array}{c}2 \\
(15 \%)\end{array}$ & $\begin{array}{c}0 \\
(0 \%) \\
\end{array}$ & $\begin{array}{c}2 \\
(3 \%) \\
\end{array}$ \\
\hline $\begin{array}{l}\text { I though other graduate employers } \\
\text { would want placement experience. }\end{array}$ & $\begin{array}{c}2 \\
(5 \%)\end{array}$ & $\begin{array}{c}1 \\
(8 \%)\end{array}$ & $\begin{array}{c}0 \\
(0 \%)\end{array}$ & $\begin{array}{c}3 \\
(4 \%)\end{array}$ \\
\hline $\begin{array}{l}\text { I thought it would give me an edge } \\
\text { over other graduates. }\end{array}$ & $\begin{array}{c}13 \\
(31 \%) \\
\end{array}$ & $\begin{array}{c}2 \\
(15 \%) \\
\end{array}$ & $\begin{array}{c}5 \\
(31 \%) \\
\end{array}$ & $\begin{array}{c}20 \\
(28 \%) \\
\end{array}$ \\
\hline $\begin{array}{l}\text { I wanted business or industry } \\
\text { experience. }\end{array}$ & $\begin{array}{c}26 \\
(62 \%) \\
\end{array}$ & $\begin{array}{c}8 \\
(62 \%) \\
\end{array}$ & $\begin{array}{c}9 \\
(56 \%) \\
\end{array}$ & $\begin{array}{c}43 \\
(61 \%) \\
\end{array}$ \\
\hline Other & $\begin{array}{c}1 \\
(2 \%) \\
\end{array}$ & $\begin{array}{c}0 \\
(0 \%) \\
\end{array}$ & $\begin{array}{c}2 \\
(13 \%) \\
\end{array}$ & $\begin{array}{c}3 \\
(4 \%) \\
\end{array}$ \\
\hline \multicolumn{5}{|l|}{ Value of the placement course } \\
\hline Learning new skills & $\begin{array}{c}0 \\
(0 \%) \\
\end{array}$ & $\begin{array}{c}1 \\
(7 \%) \\
\end{array}$ & $\begin{array}{c}0 \\
(0 \%) \\
\end{array}$ & $\begin{array}{c}1 \\
(1 \%)\end{array}$ \\
\hline $\begin{array}{l}\text { Networking with people in the } \\
\text { industry }\end{array}$ & $\begin{array}{c}2 \\
(5 \%)\end{array}$ & $\begin{array}{c}0 \\
(0 \%)\end{array}$ & $\begin{array}{c}3 \\
(19 \%)\end{array}$ & $\begin{array}{c}5 \\
(7 \%)\end{array}$ \\
\hline A possible graduate job & $\begin{array}{c}7 \\
(17 \%) \\
\end{array}$ & $\begin{array}{c}6 \\
(46 \%) \\
\end{array}$ & $\begin{array}{c}1 \\
(6 \%) \\
\end{array}$ & $\begin{array}{c}14 \\
(20 \%) \\
\end{array}$ \\
\hline Earning money & $\begin{array}{c}11 \\
(26 \%) \\
\end{array}$ & $\begin{array}{c}3 \\
(23 \%) \\
\end{array}$ & $\begin{array}{c}7 \\
(44 \%) \\
\end{array}$ & $\begin{array}{c}21 \\
(30 \%) \\
\end{array}$ \\
\hline $\begin{array}{l}\text { Your placement provided experience } \\
\text { for your final-year project }\end{array}$ & $\begin{array}{c}19 \\
(45 \%)\end{array}$ & $\begin{array}{c}3 \\
(23 \%) \\
\end{array}$ & $\begin{array}{c}5 \\
(31 \%) \\
\end{array}$ & $\begin{array}{c}27 \\
(38 \%) \\
\end{array}$ \\
\hline Other & $\begin{array}{c}3 \\
(7 \%)\end{array}$ & $\begin{array}{c}0 \\
(0 \%)\end{array}$ & $\begin{array}{c}0 \\
(0 \%)\end{array}$ & $\begin{array}{c}3 \\
(4 \%)\end{array}$ \\
\hline
\end{tabular}




\section{Benefits of placement}

Placed students across the three schools highlight the benefits of placement to their academic performance through their final-year project. Our survey found that students who have been on a placement have gained ideas about their final-year project (Table 6) and have returned to the university with more in-depth knowledge of their subject area. Mandilaras (2004) asserted that placement students mature more rapidly by working in a competitive and professional environment, and they return to the university more focused and determined to achieve high grades. The various responsibilities that students have undertaken during their placements have made them more responsible and reliable. Thus, they take coursework and exams more seriously, and they work more effectively with tight deadlines. All the above skills help them to improve their time management skills and, consequently, their academic performance. Several empirical studies (e.g., Gomez et al., 2004; Rawlings et al., 2005; Surridge, 2007) support this argument claiming that placement has a significant positive effect on final-year grades.

\section{CONCLUSION}

This study analyzes the motivations and barriers in undergraduate university students' decisions to enroll in placement courses in the UK. The survey found that non-placement students' lack of confidence in issues related to employment as well as their lack of relevant work experience and desire to focus on achieving a $1^{\text {st }}$ or a 2.1 degree classification prevents them from seeking a placement. On the other hand, placement students select to follow a placement course motivated by factors such as the salary rate, location of the placement employer, benefits from industry experience, and the fact that placements help them in their final-year project.

The study contributes to the existing research in the field of higher education in several ways. Based on data with 117 non-placement and 71 placement students, the study examines the various factors that encourage students across three schools of Brunel University to take or not take a placement course. Second, it identifies the barriers that prevent students from enrolling in a placement course. The last contribution aims to assist the PCC to develop a strategic plan that will promote undergraduate placement courses, which enhance students' employability.

Based on the findings of this study, the recommendations are as follows:

- $\quad$ First, placements should be promoted to students, and potential barriers to access should be removed. Course-related work experience will help students to acquire practical knowledge in their fields and assist them in developing employability skills through employment-based training. In addition, course-related work experience will give them confidence and motivate them to apply for placement courses. Such course-related work experience can take place in either an office or a company environment. Its purpose is to improve students' placement application skills, interview techniques, and presentation techniques that will enhance their confidence. In order to increase the number of placement students per year, universities must make more placements available and ensure that students know where to look for them. Universities should provide to realistic information on the timetable, time, and effort required to gain a placement. Further, the experiences of successful placement students might be presented on the university website in the form of a podcast in order to publicize their benefits widely.

- $\quad$ Second, placement courses and their associated benefits should be promoted to instructors at staff inductions and through the placement coordinator of each school. The placement coordinator of each school should have the relevant expertise, time, and resources to manage the whole process effectively. $\mathrm{He} / \mathrm{she}$ should also be responsible for finding suitable placements as well as preparing, monitoring, assessing, and debriefing students. Placement action should be built into the academic staff appraisal system so that all academic staff members are expected to contribute.

- $\quad$ Third, placement should be active promoted to parents as well as to potential students by sending them an employability guide that will advise them of the benefits of a placement. Promoting placements to the parents of university students is very important given the finding that parental support is crucial in students' decisions regarding placement. Parents of first-year students might also be invited to presentations given by placement students willing to share their experiences and their current employment status.

- $\quad$ Finally, placement courses can be promoted by utilizing business links that will generate business and placement opportunities for students. Advisory board members, alumni, and other influential people can be 
asked to consider placement opportunities. Additionally, Brunel University must establish links with local employers, as students expressed a preference not to relocate. Therefore, it is crucial for the promotion of placement courses to target SME employers within the M25 area so that students can accept placements without moving away from home. SME companies, due to their small size, often do not have wellorganized human resources departments, but at the same, they are looking for potential employees. SMEs provide potential placement students with challenging opportunities that are available immediately without bureaucratic processes. Moreover, employer-led lectures should be incorporated into the curriculum at Levels 1 and 2 to familiarize students with business practices and help them apply their theoretical knowledge. Overall, the undergraduate studies curriculum across the university has to be re-designed with industry input in mind.

\section{AUTHOR INFORMATION}

Dr. Maria Elisavet Balta has a Ph.D. in Strategy from Brunel Business School, where she is currently a lecturer of Strategy. Her main interests are in strategic management, strategic decision making, innovation practices, and the strategic development of social enterprises as well as higher education issues and students' employability. Her recent work appears in the Journal of Economic Asymmetries, Journal of Applied of Business Research, Corporate Board: Role, Duties and Composition, and Corporate Ownership and Control. E-mail: Maria.Balta@brunel.ac.uk (Corresponding author)

Dr. Jane Coughlan is a lecturer in the Department of Information Systems and Computing, Brunel University. She has over 10 years' experience researching design and usability of electronic environments, user behavior with technology, and the nature of communication that influences interaction in areas such as relationship management, pedagogical effectiveness of e-learning environments using multimedia, and service quality within e-business environments. She has a B.A. in Psychology and a Master's of Research in Informatics, both from the University of Manchester, and a Ph.D. from Brunel University. She actively participates in teaching initiatives aimed at improving the student experience. She leads a JISC-funded project on use of social media to support e-mentoring relationships for career development and employability. E-mail: jane-lisa.coughlan@brunel.ac.uk

Dr. Peter Hobson has a B.Sc. in Physics from Edinburgh University and a Ph.D. in Particle Physics from University College London and is a Chartered Physicist. He has been a member of staff at Brunel University since 1986, where he is currently a Professor, Director of the Centre for Sensors \& Instrumentation, and the Deputy Head of the School of Engineering \& Design, with particular responsibility for undergraduate programs. His main fields of research are Particle Physics, Holography, and Grid Computing; additionally, he has particular interests in academic workload management, research ethics, and student employability. E-mail: Peter.Hobson@brunel.ac.uk

\section{ACKNOWLEDGMENTS}

The authors are grateful to the Higher Education Careers Service Unit (HECSU) for funding this research.

\section{REFERENCES}

1. Alderman, B. and Milne, P. (1998). Partners in Learning - educators, practitioners and students collaborate on work-based learning - a case study. Higher Education Research and Development, 17(2) 229-238.

2. Archer, W. and Davidson, J. (2008). Graduate Employability: The views of employers, London: The Council for Industry and Higher Education.

3. Auburn, T. and Ley, A. (1993). Psychology Undergraduates' Experience of Placements: A role-transition perspective. Studies in Higher Education, 18(3) 265-285.

4. Ball, C., Collier, H., Mok, P. and Wilson, J. (2006). Research into barriers to work placements in the retail sector in the South East, National Council for Work Experience, Higher Education Careers Service Unit and the National Council of Work Experience for Skill smart Retail and the South East Economic Development Agency.

5. Barthorpe, S. and Hall, M. (2000). A collaborative approach to placement preparation and career planning for university students: a case study. Journal of Vocational Education \& Training, 52(2)165 - 175. 
6. Birks, M. (1996). Enterprise in Higher Education and the graduate labour market. Journal of Education and Training, 38(2) 26-29.

7. Blackwell, A. and Harvey. L. (1999). Destinations and reflections: Careers of art, craft and design graduates. Birmingham: Centre for research into Quality available at http://www.uce.ac.uk/crq/publications/dr/index.html

8. Blackwell, A., Bowes, L., Harvey, L., Hesketh, A.J. and Knight, P.T. (2000). Transforming work experience in higher education. British Educational Research Journal. 27(3) 269-86.

9. Bowes, L. and Harvey, L. (2000). The Impact of Sandwich Education on the Activities of Graduates Six Months Post-Graduation. London: National Centre for Work Experience and the Centre for Research into Quality.

10. Brennan, J. and Little. B. (1996). A Review of Work Based Learning in Higher Education. London: DfEE.

11. Brennan, J. and Little, B. (2006). Towards a Strategy for Workplace learning. Milton Keynes: Open University Centre for Higher Education Research and Information.

12. Bridgestock, R. (2009). The graduate attributes we've overlooked: Enhancing graduate employability through career management skills. Higher Education Research and Development, 28(1) 31-44

13. Broadbridge, A. and Swanson, V. (2005). Earning and learning: How term-time employment impacts on students' adjustment to university life. Journal of Education and Work, 18(2) 235-49.

14. Brown, G. (2010) Securing sustainable future for higher education: An independent review of higher education funding and student finance. Report. London.

15. Clarke, T. (2008). The Business schools: 50 years on. Journal of Education and Training, 50(1) 52-54.

16. Confederation of British Industry (2009). Future Fit: Preparing Graduates for the World of Work, London: Confederation of British Industry Higher Education Task Force.

17. Connor, H. and Shaw, S. (2008). Graduate training and development: Current trends and issues. Journal of Education and Training, 50(5) 357-365.

18. Curtis, S. and Shani, N. (2002). The effects of taking paid employment during term time on students' academic studies. Journal of Further and Higher Education, 26(2) 129-138.

19. Dale, I. and Kerr, J. (1995). Small and medium-sized enterprises: their numbers and importance to employment. Labour Market Trends, December, pp.461-66.

20. Davidson, 1., J. Brown. and M. Davison. (1993). Employer satisfaction ratings of recent business graduates. Human Resource Development Quarterly, 4(4) 391-399.

21. Davies, L. (2003). Experience-based learning within the curriculum - a synthesis study, Sheffield, Association for Sandwich Education and Training.

22. De la Harpe, B., Radloff, A. and Wyber, J. (2000). Quality and generic (professional) skills. Quality in Higher Education, 6 (3) 231-43.

23. Deissinger, T. (2000). The German "philosophy" of linking academic and work-based learning in higher education: the case of the vocational academies. Journal of Vocational Education and Training, 52( 4) 605626.

24. BIS (2009). Higher Ambitions: The future of universities in a knowledge economy. London, Department for Business, Innovation and Skills.

25. Denzin, N. (1989). Interpretive biography. Sage University Paper Series on Qualitative Research Methods, 17, Newbury Park: Sage.

26. Department for Education and Skills (2003). The Future of Higher Education. Norwich: HMSO.

27. Department of Trade and Industry (DTI), (2000), Small and medium Enterprise (SME) Statistics for the UK, 1999, Statistical News Release, 7 August, London.

28. Dfes (2003). Statistics of Education: Education and training statistics for the United Kingdom. London: TSO.

29. Dillman, D. A. (2000). Mail and Internet Surveys--The Tailored Design Method. New York :John Wiley \& Sons, Inc Education', 428-31, Edinburgh, Napier College

30. Ellis, N. (2000). Developing graduate sales professionals through co-operative education and work placements: A relationship marketing approach. Journal of European Industrial Training, 24(1) 34-42.

31. Falconer, S. and Pettigrew, M. (2003). Developing added value skills within an academic programme through work-based learning. International Journal of Manpower, 24(1) 48-59.

32. Foster, E. and Stephenson. J. (1998). Work based learning and universities in UK: A review of current practice and trends. Higher Education Research + Development, 17 (2) 155-170. 
33. Freudenberg, B., Brimble, M. \& Cameron, C. (2011). WIL and generic skill development: The development of business students' generic skills through work-integrated learning. Asia-Pacific Journal of Cooperative Education, 12(2) 79-93.

34. Frey J. and Fontana A. (1993). The Group Interview in Social Research. In: D. L. Morgan (eds) Successful Focus Groups: Advancing the State of the Art. Newbury Park, CA: Sage.

35. Gault, J., Leach, E., \& Duey, M. (2010). Effects of business internships on job marketability: the employers' perspective. Education + Training, 52(1) 76-88

36. Gomez, S., Lush, D. and Clements, M. ( 2004). "Work placements enhance the academic performance of Bioscience undergraduates. Journal of Vocational Education and Training ,56 (3) 373-386.

37. Hall, R. (2010). The Work-study relationships: Experiences of full-time university students undertaking part-time employment. Journal of Education and Work, 23(5) 439-449.

38. Harvey, L. and Contributors (2003). Transitions from higher education to work. Centre for Research and Evaluation. Sheffield Hallam University. Available at www.heacademy.ac.uk/2604.htm

39. Harvey, L., Geall, V., and Moon, S. with Aston, J., Bowes, L. and Blackwell, A., (1998). Work Experience: Expanding opportunities for undergraduates. Birmingham: Centre for Research into Quality.

40. Harvey, L., Moon, S. and Geall, V. (1997). Graduates' work: Organisation change and students' attributes. Birmingham, Centre for Research into Quality (CRQ) and Association of Graduate Recruiters (AGR). Available at http://www.uce.ac.uk/crq/publications/gw

41. Heaton, N., McCracken, M. and Harrison, J. (2008). Graduate recruitment and development: sector influence on a local market/regional economy. Journal of Education and Training, 50(4) 276-88.

42. Higher Education Funding Council for England (HEFCE). (2009). Attainment in higher education: Erasmus and placement students. Bristol, England: HEFCE.

43. Higher Education Funding Council for England (HEFCE). (2002). Higher Education Active Communities Fund. England: HEACF. http://www.hefce.acuk/Reachout/heacf

44. HEFCU/AGCAS (2010). What graduates do? HECSU/AGCAS.

45. Higher Education Policy Institute. (2010). Postgraduate Education in the United Kingdom. Ginerva House, London: British Library.

46. Higher Education Statistical Agency (HESA) (2011). Definition of students and qualifiers statistics. http://www.hesa.ac.uk/index.php/content/view/1902/

47. Hughes, C. (1998). Practicum learning: Perils of the authentic workplace. Higher Education Research \& Development, 17(2) 207-227.

48. Jackson, S. (1995). Work-based learning for academic credit. Journal of Geography in Higher Education, 19 (2) 217-222.

49. Johnson, D. (2000). The use of learning theories in the design of a work-based learning course at masters level. Innovations in Education and Training International, 37(2) 129-133.

50. Johnson, S. and Burden, T. (2003). Young people, employability and the induction process. York: Joseph Rowntree Foundation www.jrf.org.uk

51. Lambert (2003), Lambert Review of Business-University Collaboration. Norwich: HMSO.

52. Lambert, E., Scarles, C., Marlow-Hayne, N., Blakeman, A., Morey, A. and Harvey, L. (2001). Employability and the media studies curriculum. Report to a consortium of four universities, July 2001, Birmingham: CRQ.

53. Leith, A. (2006). Prosperity for all in the global economy- world class skills, The Leith Report) available www.hm-treasury.gov.uk/media/6/4/leith-final report 051206.pdf

54. Leslie, D. and Richardson, A. (2000).Tourism and cooperative education in U.K undergraduate courses: Are the benefits being realised?. Tourism Management, 21(5) 489-498.

55. Little, B. and Harvey, L. (2006). Learning through work placements and beyond. HEA.

56. Mandilaras, A. (2004). Industrial placement and degree performance: Evidence from a British Higher Education. International Review of Economics Education, 3(1) 39-51.

57. Marshall, I. and Cooper, L. (2001), Earning academic credit for part-time work, In D. Boud and N.Solomon (Eds) Work-based learning: a new higher education? Buckingham: Open University Press, pp. 184-99.

58. Mason, G., Williams, G. and Cranmer, S. (2009). Employability skills initiatives in higher education: what effects do they have on graduate labour market outcomes?. Education Economics, 17(1) 1-30.

59. McMahon, U and Quinn, U. (1995). Maximising the hospitality management student work placement experience: a case study. Journal of Education and Training, 37(4)13-17. 
60. Medhat, S. (2003). A new beginning for a strained relationship. Times Higher Education Supplement, 24, Issue: January, p. 18.

61. Moreau, M. and Leathwood, C. (2006). Balancing paid work and studies: working (-class) students in higher education. Studies in Higher Education, 31(1) 23-42.

62. Mortimer, G. and Wilkinson, J. (2003). The employment perspective and the business curriculum: work in progress. Thames Valley University.

63. National Committee of Inquiry into Higer Education (NCIHE) (1997). Higher Education in the Learning Society, London: HMSO.

64. National Council for Work Experience (NCWE) (2002). Work Related Learning Report, February. Nottingham, DfES.

65. OECD (2003). Education at glance. Available online at: http://www.oecd.org/document/52/.html

66. Page, B. (2004). The barriers to the take-up of sandwich and other work placements by inner city multiethnic students. London Metropolitan University.

67. Parilla, P.F. and Hesser, G.W. (1998). Internships and the sociological perspective: Applying principles of experiential learning. Teaching Sociology, 26(4) 310-329.

68. Rawlings, P., White, P. and Stephens, R. (2005). Practice-Based learning in Information Systems: The advantages for students. Information Systems Education, 16(4) 455-63.

69. Ryan, G., Yan, G., Toohey, S. and Hughes, C. (1996). The purpose, value and structure of the placement in higher education: a literature review. Higher Education, 31(3) 355-377.

70. Schonfield, G. (2005). The voice of the child in family placement decision making: A developmental model. Adoption and Fostering, 19(1) 29-44.

71. Sewell, P. (2001). Higher level skills in creative industries in Lancashire and Cumbria, LMI Briefing, 26 July. North West Labour Market Partnership. http://www.lmi4he.ac.uk/Documents/brief 26.doc

72. Smith, P.J., Henry, J. and Munro. G. (2002). Training young people through a school/enterprise partnership: a longitudinal study. Journal of Education and Training, 44(6) 281-9.

73. Smith, E. and Kemmis, R. (2010). What industry wants: Employers' preferences for training. Journal of Education and Training, 52(3) 214-225.

74. Stoner, G. and Milner, M. (2008). Embedding generic employability skills in an accountancy degree development and impediments. Paper presented at the Business, Management, Accountancy and Finance Higher Education Conference, April 2008, Edinburgh.

75. Surridge, I. (2007). Determinants of performance on an accounting and finance degree. British Accounting Association Accounting Education Special Interest Group conference. May 2007.

76. Universities UK/CBI report (2009). Future Fit-preparing graduates for the world of work http://www.universitiesuk.ac.uk/publications/documents/futurefi.pdf

77. Walker, F. and Ferguson, M. (2009). Approaching placement extinction: Exploring the reasons why placement students are becoming a rare breed at the University of Central Lancashire, working paper, University of Central Lancashire.

78. Wilson, K., Sinclair, L. and Gibbs, I. (2000). The trouble with foster care: the impact of stressful events on foster carers. British Journal of Social Work, 30 193-209.

79. Wilton, N. (2008). Business graduates and management jobs: an employability match made in heaven?. Journal of Education and Work, 21(2) 143-158.

80. Wrennall, M. and Forbes, D. (2002). I have learned that psychology is linked to almost everything we do. Developing and evaluating the impact of a work-based learning module in an undergraduate psychology programme. Psychology Teaching Review, 10(1) 90-101.

81. Young, W. (1995). Internship: Integrating theory and practice. South Pacific Journal of Teacher Education, 23(1) $97-107$. 


\section{NOTES}

